\title{
Microbial contaminants of cultured Hibiscus cannabinus and Telfaria occidentalis tissues
}

\author{
Odutayo O. I. ${ }^{1 *}$, Oso R. T., ${ }^{1}$ Akinyemi B. $0 .{ }^{1}$ and Amusa N. A. ${ }^{2}$ \\ ${ }^{1}$ Dept of Biological Sciences, Olabisi Onabanjo University, Ago- Iwoye, Nigeria. \\ ${ }^{2}$ Institute of Agricultural Research and Training, Obafemi Awolowo University, PMB 5029 Moor Plantation, Ibadan, \\ Nigeria. \\ Accepted 10 August, 2004
}

\begin{abstract}
Nine microbial contaminants comprising of five bacteria and four fungi species were isolated from Hibiscus cannabinus and Telfaria occidentalis cultured tissues. The rate of occurrence of bacteria isolates was higher than that of fungi. The bacterial isolates includes Pseudomonas syringae pv phaseolicoli, Bacillus licheniformis, Bacillus subtilis, Corynebacterium sp and Erwinia sp. While fungal contaminats includes Alterneria tenius, Aspergillus niger, Aspergillus fumigatus and Fusarium culmorum. Possible sources of contamination and means of eliminating these contaminants is discussed.
\end{abstract}

Key words: Micro-propagation, plant tissue culture, bacterial and fungal isolates, contamination.

\section{INTRODUCTION}

Plant tissue culture (micro-propagation) is a tool, which allows the rapid production of many genetically identical plants using relatively small amounts of space, supplies and time. Basically the technique consists of taking a piece of a plant (such as a stem tip, node, meristem, embryo, or even a seed) and placing it in a sterile (usually gel-based) nutrient medium where it multiplies. The formulation of the growth medium depends upon whether it is intended to produce undifferentiated callus tissue, multiply the number of plantlets, grow roots, or multiply embryos for "artificial" seed.

The nutrient media in which the plant tissue is cultivated is a good source of nutrient for microbial growth. These microbes compete adversely with plant tissue culture for nutrient. The presence of these

\footnotetext{
*Corresponding author. E-Mail: naamusa@softhome.net.
}

microbes in these plant cultures usually results in increased culture mortality, the presence of latent infections can also result in variable growth, tissue necrosis, reduced shoot proliferation and reduced rooting (Kane, 2003).

The tissue culture techniques usually involves growing stock plants in ways that will minimize infection such as treating the plant material with disinfecting chemicals to kill superficial microbes and sterilizing the vessels, tools used for dissection, and media in which cultures are grown (George, 1993). However, contamination has been reported as constant problem, which can compromise development of all in vitro techniques. (Enjalric et al., 1988).

Leggatt et al. (1994) reported the isolation and characterization of thirty-one microorganisms from ten different plant cultivars growing in micro-propagation, with yeasts, Corynebacterium spp. and Pseudomonas spp. being predominant. Hennerty et al. (1994) also isolated 
Bacillus sp., Corynebacterium sp. and an Actinomycete from the in vitro culture of apple rootstocks

The aim of this research was to investigate, isolate and identify microbial contaminants of cultured Telfaria occidentalis and Hibiscus cannabinus tissues and determine sources of contamination.

\section{MATERIALS AND METHODS}

\section{Plant materials}

The plant explants used are seeds of three different varieties of $H$. cannabinus (Tianug, Ife 100 and Ifeken 400) and nodes of $T$. occidentalis. The plant tissue culture medium used was Murashige and Skoog (1962) medium and sterilized by autoclaving at $121^{\circ} \mathrm{C}$ for $15 \mathrm{~min}$.

\section{Sterilization and incubation of plant cultures}

The explants were excised and surfaced sterilized by immersion into a $0.75 \% \mathrm{NaOCl}$ solution for 20 min after rinsing with $70 \%$ ethanol for $15 \mathrm{~s}$. The explants were rinsed in 4 successive changes of sterile distilled water. The excised explants were then aseptically transferred to the culture medium, labeled and incubated at $23 \pm 1^{\circ} \mathrm{C}$ during the day and $19 \pm 1^{\circ} \mathrm{C}$ at night for 3 weeks.

\section{Isolation of microbial contaminants}

From the contaminated plant tissue culture tubes, emerging microbes were isolated by inoculating them on Acidified Potato Dextrose Agar (APDA) and incubated for 6 days at $26^{\circ} \mathrm{C}$ under 12 $\mathrm{h}$ photoperiod in the case of fungi and further incubated on Nutrient Agar for 3 days at $30^{\circ} \mathrm{C}$ under $12 \mathrm{~h}$ photo-period. Pure isolates obtained from repeated sub-culturing of the isolates which were placed in an agar slant in MacCarthney bottles and stored at $4^{\circ} \mathrm{C}$ in a refrigerator.

\section{Characterization and identification of isolates}

The fungal isolates were identified using cultural characters and morphology and by comparison with standards (Barnet and Hunter, 1972). In case of bacteria, beside the morphological characteristics, a number of biochemical and physiological tests were carried out on the isolates. The biochemical tests includes Gram staining, spore staining, motility test, catalase production, oxidase test, indole production, citrate utilization, urease activity, hydrogen sulphide production, gelatin hydrolysis, starch hydrolysis and carbohydrate utilization.

\section{RESULTS AND DISCUSSION}

Fungal and bacterial contaminants were found associated with the cultured plant materials. The rate of occurrence of bacteria isolates was higher than that of fungal isolates (Figure 1). The bacterial isolates include Pseudomonas syringae pv phaseolicoli, Bacillus licheniformis, Bacillus subtilis, Corynebacterium sp and Erwinia sp. While fungal contaminants include Alterneria tenius, Aspergillus niger, Aspergillus fumigatus and

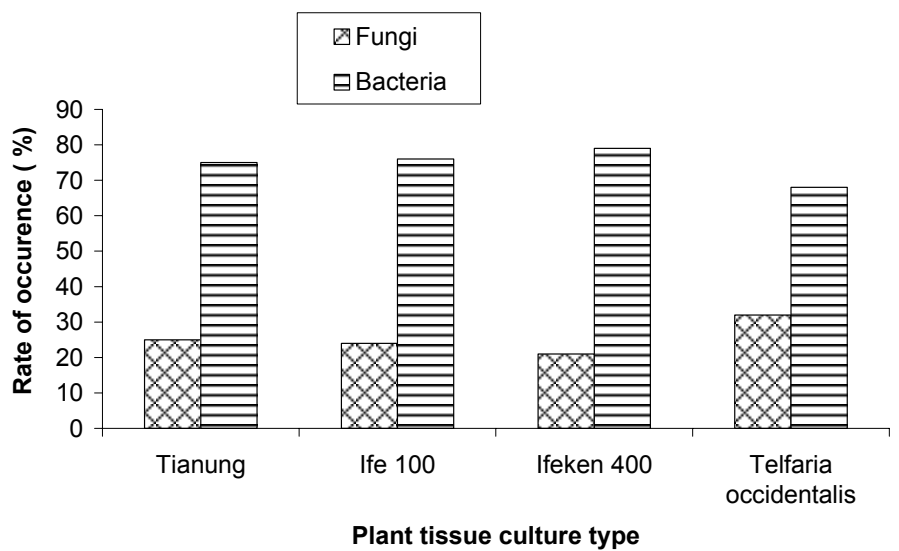

Figure 1. The rate of occurence of the microbial contaminats in plant tissue culture.

Fusarium culmorum. The rates of occurrence of these microbial isolates are as shown in Figures 2 and $3 . P$. syringae pv phaseolicoli was found to be the most prevalent contaminant in all the plant cultures but was not detected in $T$. occidentalis. Erwinia spp. was detected only in $T$. occidentalis (Figure 2). The rate of occurrence of these bacteria contaminants in these plant cultures is probably an indication that their presence was not just accidental. Hennerty (1994) reportedly identified Bacillus sp., a Corynebacterium sp. and an Actinomycete as contaminants in the M29 rootstocks. Boxus and Terzi (1998) in the course of twelve years of mass production of strawberry plants and woody species, reported problems Acinetobacter, Corynebacterium, Enterobacter (Erwinia), Flavobacterium, Pseudomonas, Torulopsis glabrata as bacterial contaminants mostly encountered in their laboratory. Most of these bacteria contaminants have been reported to increase culture mortality and the presence of latent infections can result in variable growth, tissue necrosis, reduced shoot proliferation and reduced rooting (Kane, 2003)

Fusarium culmorum was found as contaminants in all the kenaf tissue culture with the incidence of occurrence ranging between $16-25 \%$. While $A$. niger had the highest rate of occurrence in Ifeken 400 (Figure 3 ). The culture of $T$. occidentalis was contaminated with $A$. tenius and $A$. fumigatus with the incidence of occurrence of 26 and $18 \%$ respectively. Fungal contaminants of plant tissue cultures have also been reported (Kane, 2003)

Although most of these contaminants might be endogenously embedded in the plant tissues (Prierik, 1988), some of the contaminant might have emanated from contaminated tools. Boxus and Terzi (1988) reported that the spread of bacterial contamination was caused by insufficient flaming of contaminated tools and by survival of bacteria in $96 \%$ ethanol for a few hours. While flaming for $5 \mathrm{sec}$ or more (till the inoculating tools become red hot) did eliminate the spread of bacterial contamination at transfers (Boxus, and Terzi, 1987), the use of Bacti-Cinerator for $12 \mathrm{~s}$, by inserting inoculating 


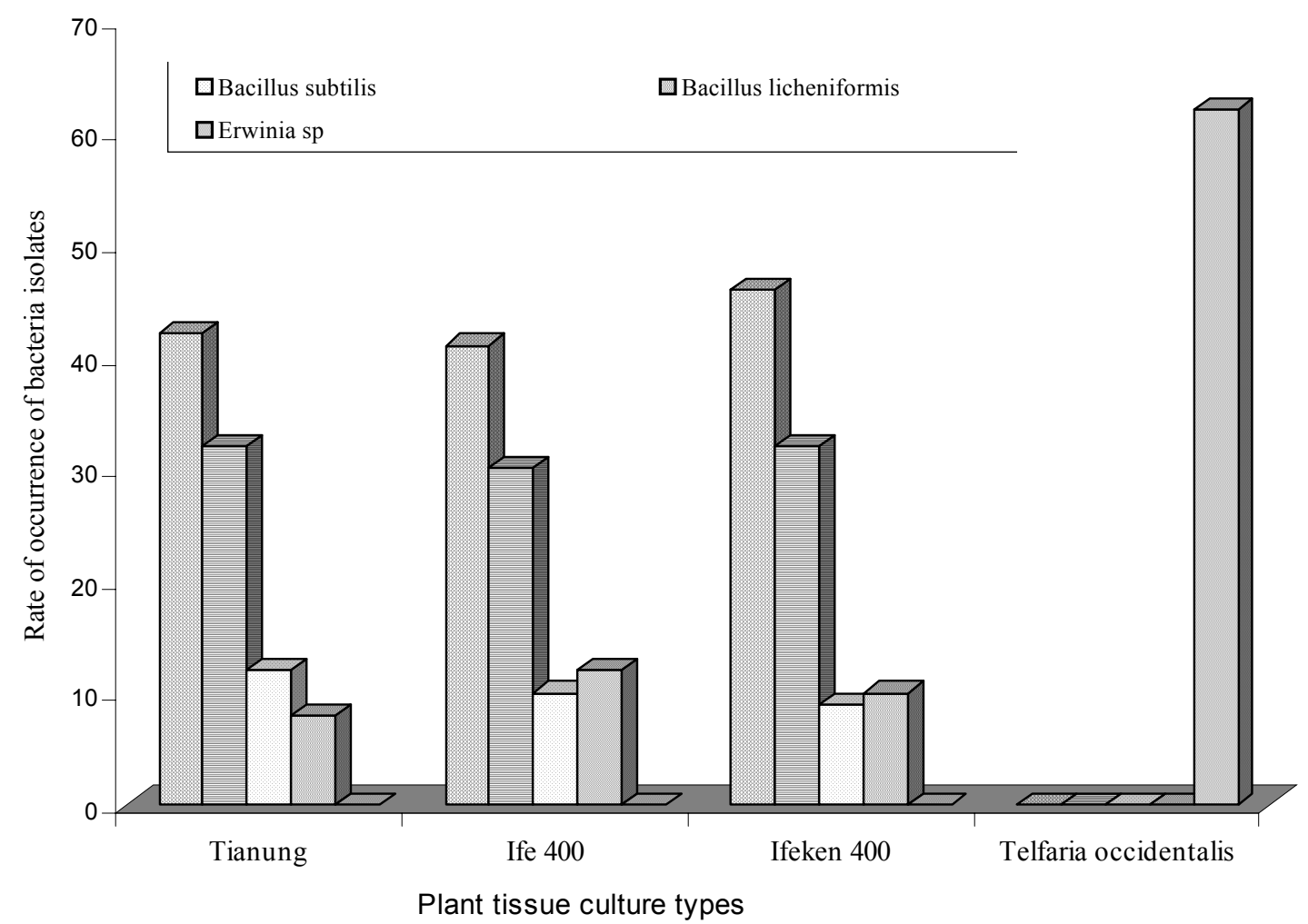

Figure 2. The occurrence of bacteria isolates in plant tissue culture.

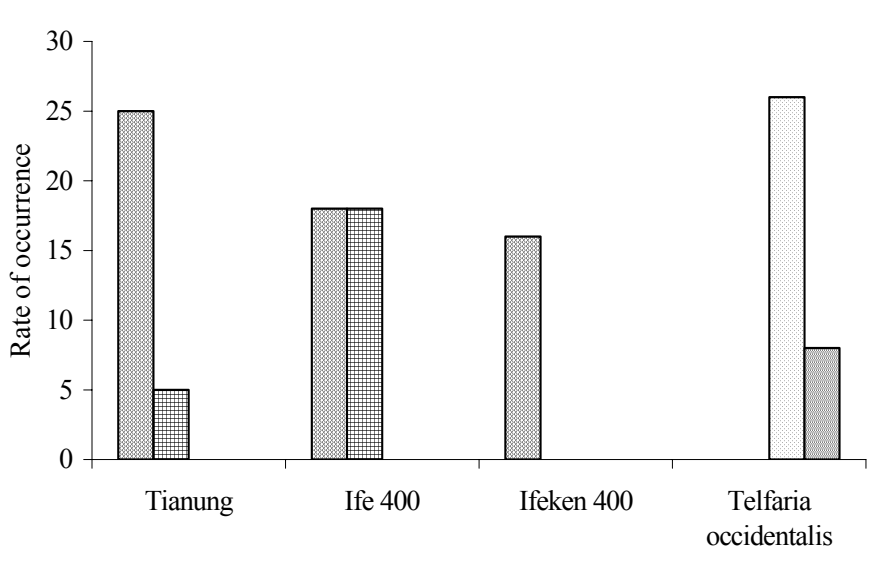

Plant tissue types

$\square$ Fusarium culmorum $\square$ Aspergillus niger $\square$ Alternaria tenius $\square$ Aspergillus fun

Figure 3. The rate of occurrence of fungal isolate in plant tissue.

tools in the middle of the heating element(and not on the edges) has also proved effective(Singha et al ., 1987).

Tissue culture vessels are always closed with loosefitting caps in order to allow gaseous exchange with the external environment. However, mites and thrips carrying fungal spores and bacteria in and on their bodies, often gain entry through this loose fittings and travel from one vessel to another thereby contaminating the cultures. Blake (1994) had earlier reported that fungal contamination of cultures is usually the first sign of a mite or thrip infestation. Hence proper sanitation and effective use of appropriate pesticides to control mites and thrips in tissue culture laboratories will be desirable. Blake (1994) has reported that thorough disinfection and strict hygiene in the laboratory have achieved effective control of microbial contaminants.

Other sources of contamination include non-adequate decontamination of explants, which allows the carry over of associated organisms from the field, or from the compost manure. Plants materials must be subjected to pesticidal treatments right from the field, and clean materials from these plants should also be planted in screen houses and be subjected again to pesticidal treatments. The mother plant materials will then have to be decontaminated again. Surface sterilization of dormant buds with mercuric chloride and sodium hypochlorite solutions has been reported to give high rates of freedom from bacterial infections, as did the use of meristems from growing shoots (Kunneman and FaaijGroenen, 1998).

During sub-culturing, man can also act as sources of contamination. Boxus and Terzi, (1987) reported the difficulty in detecting an unconsciously transmitted contaminants by workers. Moreover, some of the bacteria present in some of the plant stocks are also frequently isolated in medical bacteriology laboratories, and were always identified as non-phytopathogenic and often considered as water and soil contaminants (Boxis and 
Terzi, 1987). Boxis and Terzi (1988) reported that coagulase-negative $S$. diptheroids and other microorganism from the skin or respiratory tracts often appear as contaminants at a later stage of plant culture growth.

Inclusion of the antibiotics, penicillin G, streptomycin or tetracycline at $10 \mathrm{\mu g} \mathrm{ml}^{-1}$ in the micropropagation media proved effective in suppressing growth of pure cultures of the bacterial contaminants. Streptomycin at the same concentration was effective against the Actinomycete (Hennerty et al., 1998). The use of antibiotics in the control of bacterial contaminants of date palm tissue has been reported (Benjama and Charkaoui, 1997).

The massive scale on which plant materials is now propagated and the supply of plants for house garden and agriculture, which are often propagated in the hundred of thousands makes the prospect of microbial contamination of even a small proportion clearly costly (Fredrick, 1998). Hence there is a need to take necessary precaution during micro propagation of plant tissues.

\section{REFERENCE}

Barnett HL, Hunter BB (1972). Illustrated Genera of Imperfect Fungi. Mineapolis: Burgress Publishing Company, Minneapolis MN, p. 241

Benjama A, Charkaoui B ( 1997). Control of bacillus contaminating date palm tissue in Micropopagation using antibiotics. In pathogen and microbial contamination using antibiotics. In Pathogen and microbial contamination management in Micropagation (Cassells A. C. Eds) Kluwer Dordrecht pp. $207-212$.

Blake J (1994) Mites and Thrips As Bacterial And Fungal Vectors Between Plant Tissue Cultures. In: Bacterial and Bacteria-like Contaminants of Plant Tissue Cultures ISHS Acta Horticulturae 225: http://www.actahort.org/books/225/index.htm.
Boxus PH and Terzi JM (1987) Big losses due to bacterial contamination can be avoided in mass propagation schemes. Acta Horticulturae 212: 91-93.

Boxus PH, Terzi JM (1988) Control Of Accidental Contaminations During Mass Propagation ISHS Acta Horticulturae 225: 198-190.

Enjalric F, Carron MP, Lardet L (1988) Contamination Of Primary Cultures In Tropical Areas: The Case Of Hevea Brasiliensis. In: Bacterial and Bacteria-like Contaminants of Plant Tissue Cultures Ishs Acta Horticulturae 225 http://www.actahort.org/books/225/index. $\mathrm{Htm}$.

Frederick R, Falkiner (1998) Consequences of antibiotic Use in Horticulture. J. Antimicrobial Chemotherapy 41: 429-431.

George E F (1993) Plant propagation by tissue culture. Exergetics Ltd., Edington, England, $574 \mathrm{p}$.

Hennerty MJ, Upton ME, Furlong PA, James DJ, Harris DP, Eaton RA (1994) Microbial Contamination Of In Vitro Cultures Of Apple Rootstocks M26 And M9: In : Bacterial and Bacteria-like Contaminants of Plant Tissue Cultures ISHS Acta Horticulturae 225: http:/www.acthort.org/book/225/index.htm.

Kane M (2003) Bacterial And Fungal Indexing Of Tissue Cultures. http://www.hos.ufl.edu/mooreweb/TissueCulture/class1/Bacterial\%20 and $\% 20$ fungal\%20indexing\%20of\%20tissue \%20cultures. doc

Kunneman BPAM, Faaij-Groenen GPM (1994) Elimination Of Bacterial Contaminants: A Matter Of Detection And Transplanting Procedures In: Bacterial and Bacteria-like Contaminants of Plant Tissue Cultures Ishs Acta Hort. 225: $183-188$.

Leggatt IV, Waites WM, Leifert C, Nicholas J (1994) Characterisation Of Micro-Organisms Isolated From Plants During Micropropagation In: : Bacterial and Bacteria-like Contaminants of Plant Tissue Cultures Ishs Acta Horticulturae 225: http://www.actahort.org/books/ 225/index.htm.

Long RD, Curtin TF and Cassells AC (1988) An investigation of the effect of bacterial contamination on potato nodal culture. In: Bacterial and Bacteria-like Contaminants of Plant Tissue Cultures Act Hort.225, 83-91. http://www.actahort.org/books/225/index.htm.

Murashige T, Skoog F (1962) A revised medium for rapid growth and bioassay with tobacco tissue culture. Physiologia Plantarum 15: 475497.

Singha S, Bissonette GK, Double ML (1987) Methods for sterilizing Instruments contaminated with Bacillus sp. HortScience 22(4): 659. 